DOI: https://doi.org/10.15407/techned2022.01.050

\title{
RESEARCH OF THE PERFORMANCE INDICATOR OF AN ELECTROMAGNETIC MILL
}

\author{
O.Makarchuk ${ }^{1,2^{*}}$, D. Calus ${ }^{2 * *}$ \\ ${ }^{1}$ Lviv Polytechnic National University, \\ 12, S. Bandera str., Lviv, 79013, Ukraine, \\ e-mail: oleksandr.v.makarchuk@Ipnu.ua . \\ ${ }^{2}$ Czestochowa University of Technology, \\ Armii Krajowej Avenue 17, p.o. box 42-200 Czestochowa, Poland, \\ e-mail: o.makarchuk@el.pcz.czest.pl ; dc@el.pcz.czest.pl .
}

The paper is devoted to the development of a way for quantitative evaluation of the performance of an electromagnetic mill, i.e. a device that converts electrical energy into energy of mechanical interaction of operating elements (millstones) with the substance being ground/mixed. The proposed way is based on processing the results of calculating the trajectories of ferromagnetic millstones of an electromagnetic mill moving in a rotating magnetic field under the action of electrodynamic forces and hydrodynamic resistance forces and limited by the space of the working chamber. The average values of the number of blows, the momentum of the force of these blows, the linear velocity of the millstones and the value of the jerk are calculated. The proposed expression for calculating the integrated non-dimensional performance indicator is calculated on the basis of the above values and allows to link the performance of the grinding process with the design indicators of the mill inductor, the size of its working chamber, quantity, shape, dimensions of millstones, etc. The results of mathematical experiments to determine this performance indicator for an electromagnetic mill with a working volume of $2090 \mathrm{~cm} 3$ and an average value of magnetic induction in the working chamber $\approx 0.12 \mathrm{~T}$ are specified. This way needs an experimental confirmation. References 11, figures 5 , table 1 .

Keywords: electromagnetic mill, grinding, mixing, mill performance, mill efficiency, number of blows of millstones, millstone force momentum, millstone jerk.

1. Introduction. In modern industrial production, when increasing the efficiency of available resources in conjunction with increasing environmental requirements is one of the most important tasks, the relevant objective is to develop research aimed at expanding the use of non-traditional physical and physicochemical effects on raw materials to intensify manufacturing of products with added value.

Electromagnetic methods of intensification of technological processes include those where the role of the effective factor is played by the electromagnetic field energy [1]. It is used in so-called electromagnetic mills (EMM) for grinding or mixing solids, emulsifying liquids and gases, aerosols, as well as for the so-called activation of the substance.

2. Analysis of Recent Research. The efficiency of the machines performing the above-mentioned functions of grinding and/or mixing through the electromagnetic field and the technological parameters of the processes carried out therein are determined by the degree of conversion of consumed energy into the materials destruction energy. The mechanism of energy transfer, stages of its conversion, as well as types and intensity of mechanical interactions depend on the method of forming the dispersing force and the machine design.

Analysis of scientific, technical and patent information in this field has shown that minimal energy losses are provided by the design of machines in which the energy of the electromagnetic field is directly converted into kinetic energy of grinding elements (grinders) without the use of special transmission mechanisms. This energy conversion method applies in machines which uses methods of dispersing materials in a mixture with grindstones, which are freely placed in their working chambers $[2,3,4]$. The most wide-spread machines include electromagnetic mills with an alternating magnetic field [5,6,7].

Theoretical studies of the dynamics of ferromagnetic millstones in the chambers of EMM $[4,8]$ show that this system creates the conditions necessary for intensive mixing and grinding of multicomponent

(C) Makarchuk O., Calus D., 2022

ORCID ID: * https://orcid.org/0000-0002-9817-6113 ; ** https://orcid.org/0000-0003-4224-7020 
systems. It is known that the magnitude of the force acting on the components of the mixture and the nature of the movement of ferromagnetic millstones depends on the magnetic properties of the material of operating elements, their geometric dimensions and quantity in the working chamber, external electromagnetic field intensity and physicochemical state of raw materials processed.

Experimental studies have shown that the intense motion of ferromagnetic millstones in the working chamber is possible only until they reach the appropriate number. The criterion for assessing the conditions in which ferromagnetic elements cease to move intensively in the working area, may be some filling factor [9]. This relationship is hard to determine, since all its parameters are interdependent. Therefore, experimental methods are usually used [10].

3. Statement of the Problem. The analysis of modern publications allows to state that:

- existing methods of EMM calculation either do not link its design indicators with the efficiency of the grinding/mixing process, or use empirical dependences developed on the basis of experimental studies and for a rather narrow range of design parameters;

- methods of optimization of process control systems are based on the results of calculations using EMM mathematical models of rather mediocre level of adequacy and those that are built on the basis of statistical processing of experimental data.

Thus, this analysis showed that the current EMM design techniques are based, at best, on statistical processing of experimental data and do not contain unambiguous recommendations that link the expected performance of the mill with the set of its design indicators.

Objective of the Study. To develop a method that will allow quantifying the EMM performance depending on the size of its working chamber, parameters and winding data of the inductor and millstones.

EMM performance is the volume or mass of a substance ground to the required fraction per time unit.

Subject of the Study. Processes of dynamic interaction between ferromagnetic millstones, the working chamber and the ground substance in a rotating magnetic field inside the working chamber, in quasisteady-state modes.

4. Research Methods. The complexity of the task, the large number of dependent variables in it and the lack of information about the priority factors of influence prompted us to conduct our own research to find indicators that have a decisive impact on the efficiency of the grinding/mixing process.

Note that all studies in the following presentation were conducted for a fixed size of the working chamber, the average value of induction, the frequency of rotation of the magnetic field of the inductor and the size of the millstones.

In our opinion, one of the above indicators may be the average number of blows of millstones $k_{u}$ for a fixed period of time. Further analysis will take into account the blows of the millstones with each other, as well as the blows with the walls of the working chamber and with the particles of the ground substance. The number of blows $k_{u}$ will be defined as the product of the average number of blows of one millstone $k_{u s}$ and the number of millstones in the working chamber $n_{m}$. We assume that the indicator $k_{u}$ is linearly related to the total EMM performance, as shown in Fig. 1, $a$.

As another indicator by which it is possible to assess the effectiveness of the grinding process we propose to consider the average value of the momentum of the force of these blows $S_{u s}$, for the same period of time.

The average value of the force pulse is obviously non-linearly related to the performance (Fig. $1, b$ ) and in the case of its direction to $\infty$, the performance of the mill should theoretically also increase to $\infty$.

a)

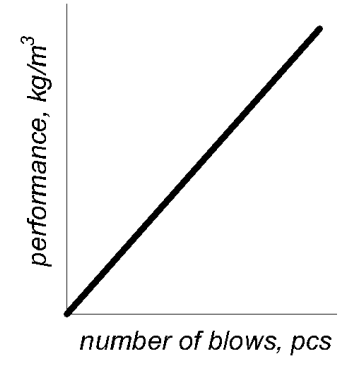

b)

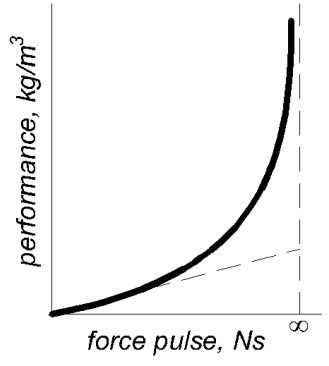

Fig. 1 c)

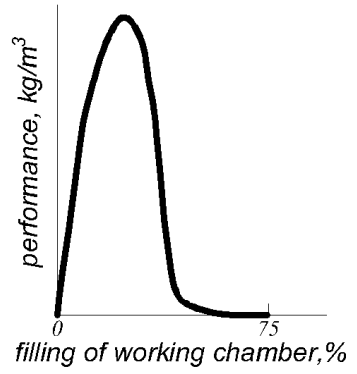

However, the initial part of this hyperbola, which corresponds to the real values of the momentum of the force, can quite successfully approach the line. Therefore, we will also take this indicator into account in 
the first degree.

The dependence of the mill performance on the filling of the working chamber with millstones $k_{w}$, in our opinion, is more complex. Obviously, if the value of the argument is zero, the performance will be zero. When the filling of the working chamber, which is approaching the theoretical maximum, we will also observe zero performance due to the cessation of the movement of the millstones. Further research accepted the filling of the working chamber with particles of working substance constant and at the level of $20 \%$. Therefore, when the filling of the working chamber millstones approaches $75-80 \%$, the performance of the mill should decrease to zero (Fig. 1,c). We propose to describe this indicator as an expression of the form $a k_{w}^{b} e^{c k_{w}}$, where $a, b, c$ are the factors that will be further selected on the basis of experimental data processing; $k_{w}$ is the filling of the working chamber in \%. At the stage of theoretical research we have accepted $a=0,01 ; b=2,1 ; c=-0,086$. Such values of the factors provide the maximum of the function at the point $k_{w}=24 \%$. The value of the indicator at it is $\approx 1.0$. Where the $k_{w}=75 \%$ indicator $\approx 0.14$. The inflection point is at the point $k_{w}=41,3 \%$.

The first and second indicators on the level of their influence on the grinding process are approximately equivalent, although careful experimental research will allow, if necessary, to introduce appropriate weighting factors for them. On the other hand, the analysis of the impact of each of the above indicators alone does not allow to draw unambiguous conclusions about the performance, and therefore each of them can not be considered self-sufficient. Only their relationship will give, to some extent, an objective idea of the performance of the mill. We propose to consider the product as such an integral indicator of performance:

$$
P_{m}=0,01 k_{w}^{2,1} e^{-0,086 k_{w}} n_{m} k_{u s} S_{u s},
$$

where $k_{w}$ is the filling of the working chamber with millstones, $\% ; n_{m}$ is the number of millstones in the working chamber;

$$
k_{u s}=\frac{1}{n_{m}} \sum_{i=1}^{n_{m}} k_{u i} ; \quad S_{u s}=\frac{1}{n_{m}} \sum_{i=1}^{n_{m}} S_{u s i}
$$

the average values of the number of blows of the millstone and the momentum of these blows; $k_{u i}$ is the number of blows of the millstone for a fixed period of time $\left(i=\overline{1, n_{m}}\right) ; S_{u s i}$ is the average pulse of the force i-th millstone for a fixed period of time $\Delta t$.

We propose hypothesis about the influence of the aforementioned indicators on the productivity of the grinding process which needs an experimental confirmation. If this hypothesis will be confirmed considering the accepted assumptions, the value of the performance indicator will be proportional to the performance of the EMM, and the use of appropriate weights will allow to use it directly to calculate the performance in $\mathrm{m}^{3} / \mathrm{s}$ or $\mathrm{kg} / \mathrm{s}$. In further research, this indicator $P_{m}$ will be used to quantify the performance of EMM.

Detection of the fact of impact of the millstone and further calculation of the momentum of the force of this impact is based on the kinematic characteristic of the material point, called the jerk, i.e. a vector quantity that determines the rate of change of acceleration of the body. The jerk is the third derivative in time from the radius vector. In our case, it is the second derivative of the velocity vector of the center of mass of the $i$-th millstone:

$$
\bar{G}_{i}=\frac{\mathrm{d}^{3} \bar{r}_{c i}}{\mathrm{~d} t^{3}}=\frac{\mathrm{d}^{2} \bar{v}_{i}}{\mathrm{~d} t^{2}}
$$

The modulus of the jerk of the $i$-th mill at the time $t=t_{k}$ is determined by its projections:

$$
\left.G_{i}\right|_{t=t_{k}}=\sqrt{G_{i x}^{2}+G_{i y}^{2}}
$$

where $k$ is the current integration step number.

To determine the projections $G_{i x}$ and $G_{i y}$ we use the mathematical apparatus of the theory of invariant approximation of functions [11]. Suppose that the tabular functions of the projections of the 
velocity of the center of mass of the $i$-th millstone are $v_{i x}(t)$ and $v_{i y}(t)$ obtained as solutions of the differential-algebraic system of equations (DAEs) of the model described in [8], can be represented at some time as Taylor polynomials of the 2 nd degree. For the $x$-projection of velocity:

$$
v_{i x}(t)=c_{1}+c_{2} t+c_{3} \frac{t^{2}}{2 !},
$$

or in a vector representation:

$$
v_{i x}(t)=\vec{T}[t] \vec{c},
$$

where $\vec{T}[t]=\left\|\begin{array}{lll}1 & t & \frac{t^{2}}{2 !}\end{array}\right\|$ is the Taylor series of 2nd degree with one independent variable; $\vec{c}=\left\|\begin{array}{lll}c_{1} & c_{2} & c_{3}\end{array}\right\|_{*}$ is the column of factors of the polynomial.

We will form a column of the discrete function $v_{i x}(t)$, which will correspond to the moment of time in which we will look for the second derivative, namely the moment $t_{k}$ :

$$
\left.\vec{v}_{i x}\right|_{t=t_{k}}=\left\|v_{x, k} \quad v_{x, k-1} \quad v_{x, k-2}\right\|_{*},
$$

where $v_{x, k}, v_{x, k-1}, v_{x, k-2}$ are the value of x-projections of velocity at times $t_{k}, t_{k-1}, t_{k-2}$, respectively.

The corresponding jerk projection, or the second velocity derivative, is defined as:

$$
\left.G_{i x}\right|_{t=t_{k}}=\frac{\mathrm{d}^{2} v_{i x}}{\mathrm{~d} t^{2}}=\vec{T}[t] D^{2} T^{-1} \vec{v}_{i x},
$$

where

$$
T=\left\|\begin{array}{ccc}
1 & t_{k} & \frac{t_{k}^{2}}{2 !} \\
1 & t_{k-1} & \frac{t_{k-1}^{2}}{2 !} \\
1 & t_{k-2} & \frac{t_{k-2}^{2}}{2 !}
\end{array}\right\|, \quad D=\left\|\begin{array}{ccc}
0 & 1 & 0 \\
0 & 0 & 1 \\
0 & 0 & 0
\end{array}\right\|
$$

- Taylor matrix and Taylor series differentiation matrix, respectively.

Analyzing (8) we can see that the projection of the jerk is numerically equal to the third factor of the Taylor polynomial $c_{3}$. This fact is used to simplify the software implementation of the presented algorithm.

Obviously, the projection of the jerk $G_{i y}$ is similar.

Having thus obtained the tabular functions $G_{i x}(t)$ and $G_{i y}(t)$, we find the current value of the modulus of the jerk in the time interval $\Delta t$ :

$$
G_{i}^{r m s}=\sqrt{\frac{1}{\Delta t} \int_{t}^{t+\Delta t} G_{i}^{2} \mathrm{~d} t}=\sqrt{\frac{1}{\Delta t} \sum_{k=1}^{K I}\left(G_{i x k}^{2}+G_{i y k}^{2}\right) \cdot\left(t_{k}-t_{k-1}\right)},
$$

where $K I$ the number of steps of integration over time, in the time interval $\Delta t$.

Comparing the current value of the module $G_{i}$ with $G_{i}^{r m s}$ the number of blows $i$-th millstone $K U_{i}$ is counted, provided:

$$
G_{i} \geq G_{i}^{r m s} \Rightarrow K U_{i}=K U_{i}+1 .
$$

The momentum of force at each moment of impact of the $i$-th millstone is determined by the expression:

$$
S_{i j}=m_{i}\left(\left(v_{i x}^{\text {end }}-v_{i x}^{\text {start }}\right)^{2}+\left(v_{i y}^{\text {end }}-v_{i y}^{\text {start }}\right)^{2}\right),
$$

where $m_{1}$ is the mass of the $i$-th millstone; $v_{i x}^{\text {start }}, v_{i y}^{\text {start }}$ are projections of the velocity of the center of mass of the $i$-th millstone at the beginning of the $j$-th impact $\left(j=\overline{1, K U_{i}}\right) ; v_{i x}^{\text {end }}, v_{i y}^{\text {end }}$ are projections of the veloc- 
ity of the center of mass of the $i$-th millstone at the end of the $j$-th impact $\left(j=\overline{1, K U_{i}}\right)$.

The average value of the momentum of the $i$-th millstone for time $\Delta t$ :

$$
S_{u s i}=\frac{1}{\Delta t} \int_{t}^{t+\Delta t} S_{i} \mathrm{~d} t=\frac{1}{K U_{i}} \sum_{j=1}^{K U_{i}} S_{i j}
$$

further used to calculate the average value of the pulse of the impact force of all millstones, according to (2).

Let us graphically illustrate this way of determining the performance indicator $P_{m}$ according to (1), on the example of a mill with a working volume of $2090 \mathrm{~cm}^{3}$, fed by a three-phase voltage of $20 \mathrm{~V}$ with compensating capacitors. The inductor winding is wye $(\mathrm{Y})$ connected, and power is supplied at a frequency of $50 \mathrm{~Hz}$ in order to reduce the cost of the mill control system. Its main dimensions are: the estimated length of the core is $185 \mathrm{~mm}$, the diameter of the working chamber is $120 \mathrm{~mm}$. The magnetic circuit of the inductor is made of electrical steel grade M600-50A, the number of poles is $2 p=2$, the wall thickness of the working chamber is $5 \mathrm{~mm}$, the number of turns in phase is 60 , the active resistance of the winding phase is 32,6 $\mathrm{mOhm}$; its inductance (excluding the saturation of the magnetic circuit) is $0,677 \mathrm{mH}$.

The average magnetic induction in the working chamber was $\approx 0.12 \mathrm{~T}$, the size of the millstones are

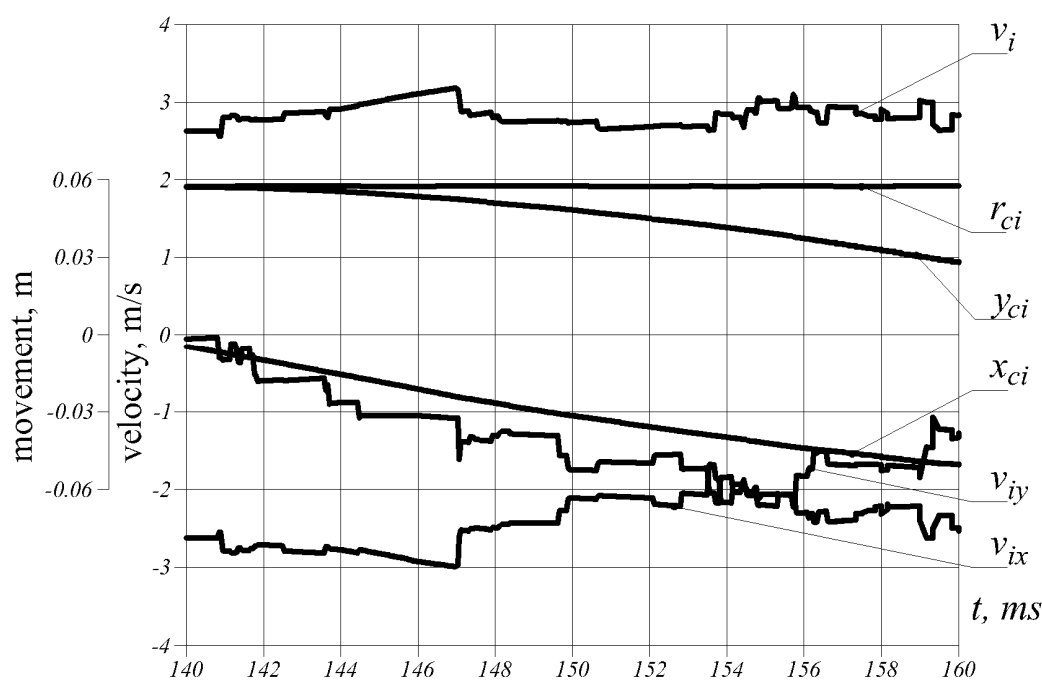

Fig. 2

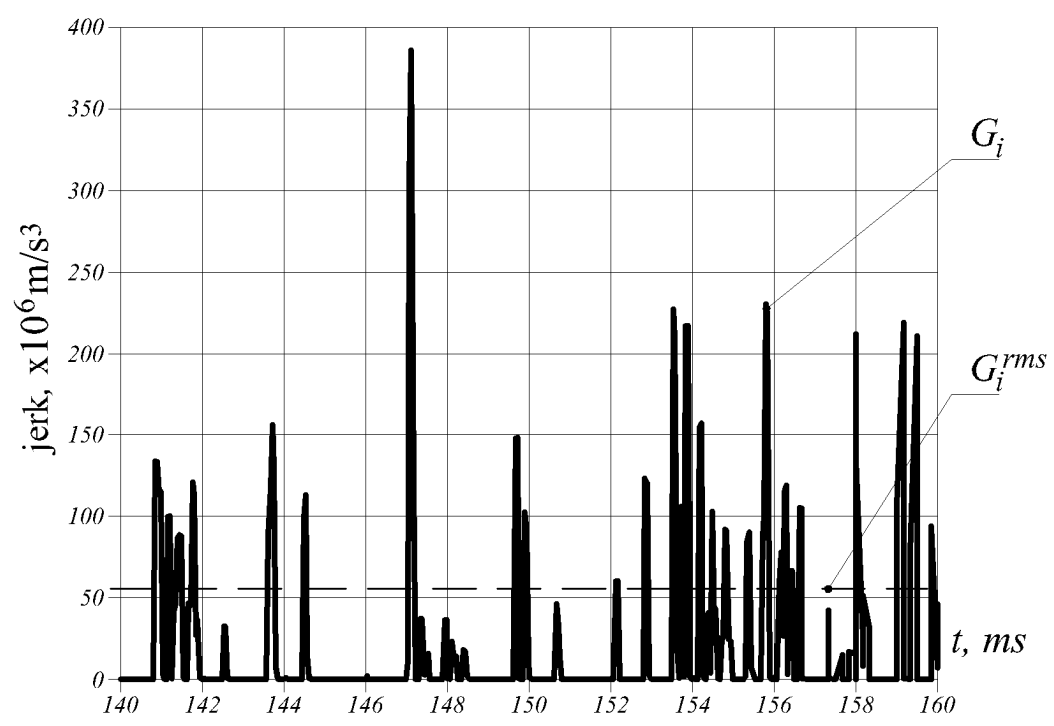

Fig. 3 $d_{m}=4,0 \mathrm{~mm}$ and $l_{m}=8 \mathrm{~mm}$, the level of filling the working chamber millstones was $10 \%$, while the level of filling with the particles of the working substance was $25 \%$. The estimated duration of the transition process was $0.16 \mathrm{~s}$. The average and current values of the calculated indicators of this process were determined during the last period, namely in the time range of $0.14 \div 0.16$ s.

Thus, Fig. 2 shows the solutions of the DAEs of the model [8], which describe the motion of a single millstone $(i=22)$ in the middle of the working chamber, namely, the

dependence on the time of projections and modules of movement and linear velocity.

Applying to the tabular functions $v_{22 x}(t)$ and $v_{22 y}(t)$ alternately the expression (8) obtained first the projection of the jerk $G_{22 x}, G_{22 y}$ and then, according to (4), its modulus $G_{22}$. The time dependence of the modulus of the jerk (4) of the millstone $i=22$ is shown in Fig. 3 . The effective value of the jerk $G_{22}^{r m s}$, calculated during the above time range by (10), is shown in the figure by a dotted horizontal line.

The correspondence between the abrupt change in the projections of the speed of the millstone and the appearance of the oscillation of the jerk can be seen in Fig. 4, where one coordinate plane shows the time dependences of these values during one of 
the blows. Let's recall that the dependence $G_{22}(t)$ is used to count the number of blows of the millstone $K U_{22}$, based on the condition (11).

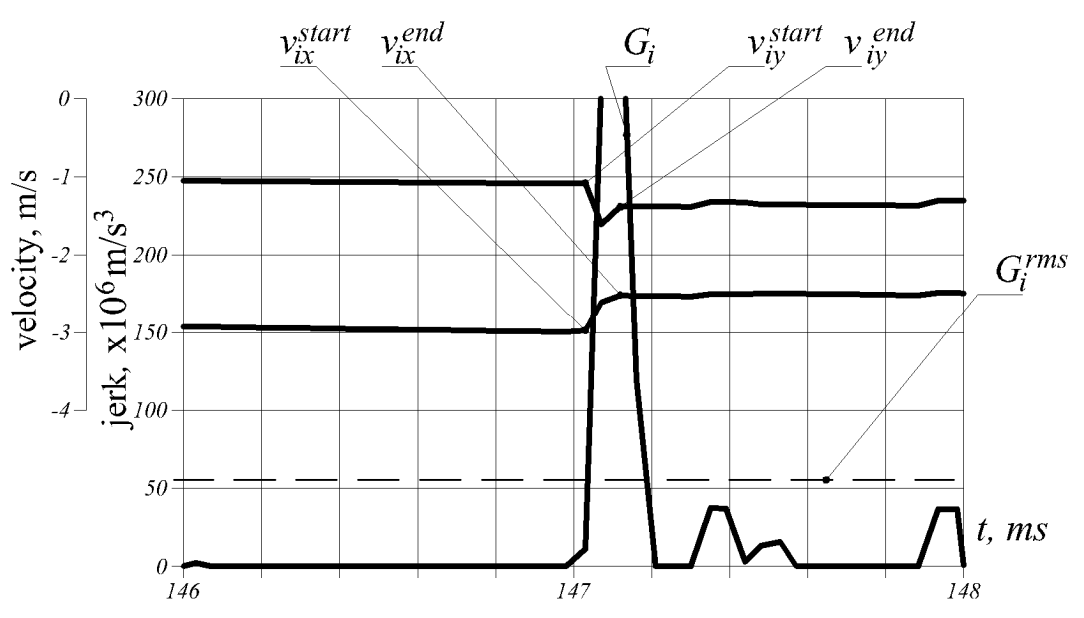

Fig. 4

The values of the projections of the linear velocity at the beginning of the blow $v_{22 x}^{\text {start }}$, $v_{22 y}^{\text {start }}$ and at its completion $v_{22 x}^{\text {end }}$, $v_{22 y}^{\text {end }}$, appearing in (12), are also shown in Fig. 4.

After performing all the above calculations, it was found that during the time interval $0.14 \div 0.16$ s for the millstone $i=22$ there were 24 blows, the momentum of the force at the time of impact, shown in Fig. 4, is equal to $2,293 \times 10^{-4}$ Ns. The average momentum of this

millstone for (13) is $7,007 \times 10^{-5} \mathrm{Ns}$.

The average number of blows calculated for the whole set of millstones $\left(n_{m}=36\right)$ for a fixed interval based on (2) is $k_{u s}=21,11$ pcs. and the average pulse is $S_{u s}=3,263 \times 10^{-5}$ Ns. Therefore, the performance of the mill $P_{m}$ in this mode is $1.35 \times 10^{-2}$.

5. Analysis of the Results. We will demonstrate the application of the presented method for estimating the performance of EMM in a mathematical experiment, the purpose of which is to study the effect of the working chamber filling on this indicator.

The experiment was performed for the mill which dimensions and winding data of which were mentioned above. Diameters of millstones is $d_{m}=2$ and $4 \mathrm{~mm}$, the size ratio is $l_{m} / d_{m}=2$, the diameters of ground particles $(\approx 5 \mathrm{~mm})$ and the level of the working chamber filling with them $(\approx 15 \%)$ were considered fixed. An independent variable in this experiment was the level of filling the working chamber with millstones $k_{w}$. Its value varied discretely in the range of $k_{w}=5 ; 10 ; 15 ; 20 ; 25 \%$.

The unknown or dependent variables were: the average number of blows of one millstone $k_{u s}$, the total number of blows of all millstones $k_{u}$ and the average value of the pulse of the force of these blows $S_{u s}$ for a fixed period of time $0.02 \mathrm{~s}$.

At the initial stage of the experiment using the model described in [4], the vector function of the vector argument was calculated in tabular form, which reflects the dependence of the electrodynamic force $F_{m}$ acting on the millstone in the middle of the working chamber on the phase of the resulting MRS of the inductor winding $\varphi$, the length of the radius vector of the center of mass of the millstone $r$, the angle of inclination of this radius vector $\gamma$. variables.

It served as input for the mathematical model [8], which was used to determine the above dependent

The results of such calculations, their analytical evaluation allow to link the dependent and independent variables and observe the causal relationships between them. In particular, the functional dependences of the above indicators on the level of the working chamber filling with millstones $k_{w}$ indicate the following (Table, Fig. 5, a). The number of blows of the millstones $k_{u}$ and $k_{u s}$ increases with increased filling $k_{w}$, which is simply due to the increase in the number of millstones. The momentum of the force increases $S_{u s}$ weakly due to the slow increase in the speed of its movement.

The performance index in the cases corresponding to the diameters of the millstones 2 and $4 \mathrm{~mm}$ increases almost equally to the filling at the level $k_{w}=20 \%$, and only further, for the millstones of larger diameter there is a more intensive growth. Also, our researches show that at bigger diameters of a millstone 
the maximum of performance is reached at $l_{m} / d_{m}=1$. An increase in the size of the millstones, such as their length, leads to an increase in the momentum of the impact force, but the number of collisions in this case will fall. The low filling of the working chamber with millstones encourages their accumulation in the vicinity of the working chamber wall, and the particles of the working substance seem to "float" over this accumulation. The grinding capacity in this case is also weak. On the other hand, overfilling of the working chamber, especially in cases where the average size of the millstone is relatively smaller than the average particle size of the working substance, enhances the effect of comprehensive coverage of these particles by the millstones. The mutual movement of these components decreases and the grinding efficiency decreases accordingly.

Results of mathematical experiments for millstones with a diameter of 2.0 and $4.0 \mathrm{~mm}$

\begin{tabular}{c|c|c|c|c|c|c}
\hline No. & $\begin{array}{c}\text { Diameter x length } \\
\text { of the millstone, } \\
\mathrm{mm}\end{array}$ & $\begin{array}{c}\text { Filling of work- } \\
\text { ing chamber } k_{w}, \\
\%\end{array}$ & $\begin{array}{c}\text { Number of mill- } \\
\text { stones } n_{m}\end{array}$ & $\begin{array}{c}\text { Number of blows } \\
k_{u s}\end{array}$ & $\begin{array}{c}\text { Momentum of } \\
\text { force } S_{u s}, \text { Ns }\end{array}$ & Indicator $P_{m}$ \\
\hline 1 & $2,0 \times 4,0$ & 5,02 & 71 & 23,39 & $6,871 \mathrm{E}-06$ & 0,00220 \\
2 & $2,0 \times 4,0$ & 10,04 & 142 & 30,99 & $7,802 \mathrm{E}-06$ & 0,01839 \\
3 & $2,0 \times 4,0$ & 15,00 & 212 & 32,72 & $8,233 \mathrm{E}-06$ & 0,04637 \\
4 & $2,0 \times 4,0$ & 20,51 & 290 & 35,10 & $8,447 \mathrm{E}-06$ & 0,08386 \\
5 & $2,0 \times 4,0$ & 25,04 & 354 & 34,83 & $8,063 \mathrm{E}-06$ & 0,09986 \\
\hline 6 & $4,0 \times 8,0$ & 5,09 & 18 & 27,83 & $4,55 \mathrm{E}-05$ & 0,00449 \\
7 & $4,0 \times 8,0$ & 10,19 & 36 & 25,69 & $4,693 \mathrm{E}-05$ & 0,02367 \\
8 & $4,0 \times 8,0$ & 15,00 & 53 & 24,70 & $5,518 \mathrm{E}-05$ & 0,05864 \\
9 & $4,0 \times 8,0$ & 20,09 & 71 & 25,54 & $4,418 \mathrm{E}-05$ & 0,07753 \\
10 & $4,0 \times 8,0$ & 25,18 & 89 & 29,38 & $5,588 \mathrm{E}-05$ & 0,14671 \\
\hline
\end{tabular}

a)

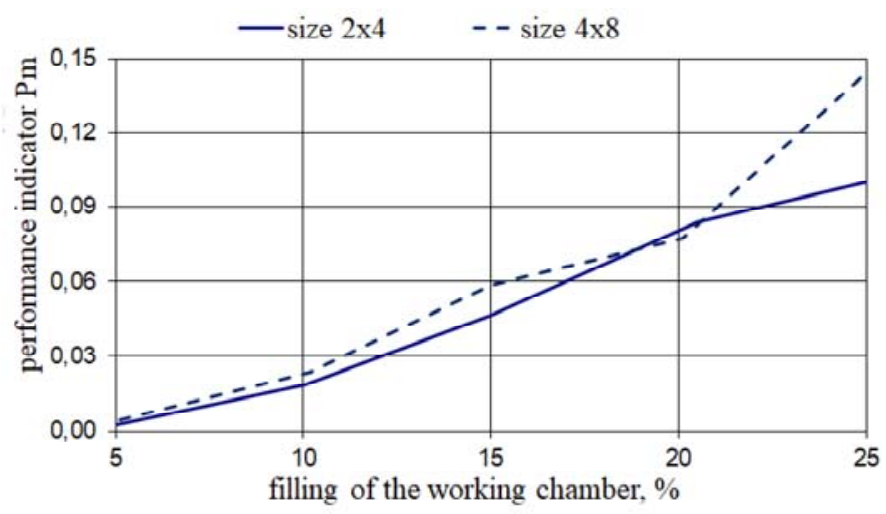

b)

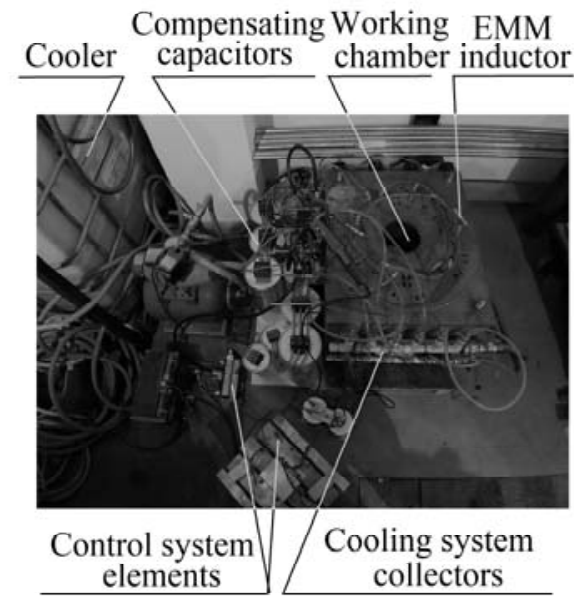

Fig. 5

We plan to test this way of determining performance and identifying the connection with the design parameters on the model of EMM with a diameter of the working chamber $120 \mathrm{~mm}$ (Fig. 5, b).

\section{Conclusions.}

1. Methods of calculation of millstones movement dynamics indicators, namely full number of their collisions (blows) and average impulse of force of these collisions are developed. The method of identifying the moments of collisions of millstones with other elements is based on the analysis of their trajectories, namely the calculation of a vector quantity called a jerk.

2. It is established that the design indicators of EMM - the diameter and length of the millstone, the level of filling the volume of the working chamber, and indicators of the dynamics of the millstone - specific number of collisions, total number of collisions, average momentum, characterize the grinding/mixing efficiency. Taking this fact into account, an original way for quantifying EMM performance was developed, based on the calculation of the so-called performance indicator (1), which takes into account the influence of the number of millstone collisions, the average momentum of these collisions and the filling level of the mill.

3. Based on the analysis of data from mathematical experiments, it was found that

- the total number of blows decreases with increased length of the millstone or its diameter, and 
increases with increased filling of the working chamber;

- the average pulse of force increases with increased size of the millstone, and decreases with increased filling of the working chamber.

4. It is assumed that the proposed performance indicator, as a scalar function, has a maximum point in the space of three design parameters of the EMM (independent variables) - the diameter of the millstone, its length and the level of filling the volume of the working chamber.

1. Logvinenko D.D., Shelyakov O.P. Intensification of technological processes in devices with a vortex layer. K.: Tekhnika, 1976. 144 p. (Rus)

2. Ogonowski S., Wolosiewicz-Glab, M., Ogonowski Z., Foszcz D., Pawelczyk M. Comparison of wet and dry grinding in electromagnetic mill. Minerals. 2018. No 8(4). P. 138. DOI: https://doi.org/10.3390/min8040138

3. Ershov D.V. Mechanochemical activation of carbon materials in an apparatus with a vortex layer. Izvestiya vyisshih uchebnyih zavedeniy. Himiya i himicheskaya tehnologiya. 2008. Vol. 51(11). Pp. 81-83. (Rus)

4. Całus D., Makarchuk O. Analysis of interaction of forces of working elements in electromagnetic mill. Przegland Electrotechniczny. 2019. No 12. Pp. 64-69. DOI: https://doi.org/10.15199/48.2019.12.12

5. Styla S. Laboratory studies of an electromagnetic mill inductor with a power source. ECONTECHMOD: An International Quarterly Journal on Economics of Technology and Modelling Processes. 2017. Vol. 6. No 2. Pp. 109-114.

6. Titov D.P. Rotor operation in the vortex layer apparatus. Vestnik Belgorodskogo gosudarstvennogo tehnologicheskogo universiteta im. V.G. Shuhova. 2020. No 3. Pp. 114-120. (Rus)

7. Sławiński K., Knaś K., Gandor M., Balt B., Nowak W. Młyn elektromagnetyczny i jego zastosowanie do mielenia i suszenia węgli. Piece przemystowe \& kotty. 2014. No 1-2. Pp. 21-25. (Pol)

8. Makarchuk O., Calus D., Moroz V. Mathematical model to calculate the trajectories of electromagnetic mill operating elements. Tekhnihna Electrodynamika. 2021. No 2. Pp. 26-34. DOI: https://doi.org/10.15407/techned2021.02.026

9. Volkov V.S., Bezzubtseva M.M., Zagaevski N.N. The issue of designing electromagnetic disk mechanoactivation in the apparatus-technological production systems, feed additives. Sovremennyie naukoemkie tehnologii. 2015. No 11. Pp. 11-13. (Rus)

10. Wegehaupt J., Buchczik D., Krauze O. Preliminary studies on modelling the drying process in product classification and separation path in an electromagnetic mill installation. IEEE. 22nd International Conference on Methods and Models in Automation and Robotics (MMAR). Miedzyzdroje, Poland, August 28-31, 2017. Pp. 849-854. DOI: https://doi.org/10.1109/MMAR.2017.8046939

11. Filts R.V. Taylor vector basis function and its application in problems of electrodynamics. Izvestiya vuzov Elektromehanika. 1989. No 9. Pp. 5-10. (Rus)

\section{УДК 621.926 .9}

ДОСЛІДЖЕННЯ ПОКАЗНИКІВ ПРОДУКТИВНОСТІ ЕЛЕКТРОМАГНІТНОГО МЛИНА

О. Макарчук ${ }^{1,2}$, Д. Цалус ${ }^{2}$

'Національний університет „Львівська політехніка”,

вул. С. Бандери 12, Львів, 79013, Україна, e-mail: oleksandr.v.makarchuk@lpnu.ua .

${ }^{2}$ Університет „Ченстоховська політехніка”,

вул. Армії Крайовей 17, 42-200 Ченстохова, Польща,

e-mail: o.makarchuk@el.pcz.czest.pl; $\underline{\text { dc} @ \text { el.pcz.czest.pl . }}$

Праия присвячена розробиі способу кількісної оцінки продуктивності електромагнітного млина - пристрою, що забезпечує перетворення електричної енергії у енергію механічної взаємодії робочих елементів (жорен) з речовиною, що розмелюється/перемішується. Пропонований спосіб заснований на обробиі результатів розрахунку траєкторій феромагнітних жорен електромагнітного млина, що рухаються в обертовому магнітному полі під дією електродинамічних сил і сил гідродинамічного опору та обмежені простором робочої камери. Обчислюються середні значення кількості ударів, імпульсу сили цих ударів, лінійної швидкості жорен та значення ривка. Запропонований вираз обчислення інтегрального безрозмірного показника продуктивності вираховується на підставі вищезазначених величин та дає змогу зв'язати продуктивність процесу розмелювання з конструкційними показниками індуктора млина, розмірами його робочої камери, кількістю, формою, розмірами жорен та ін. Наведено результати математичних експериментів з визначення иього показника продуктивності для електромагнітного млина з робочим об'ємом $2090 \mathrm{~cm}^{3}$ та середнім значенням магнітної індукції у робочій камері $\approx 0,12$ Тл. Спосіб потребує експериментального підтвердження. Бібл. 11, рис. 5 , табл. 1.

Ключові слова: електромагнітний млин, розмелювання, перемішування, продуктивність млина, ефективність млина, кількість ударів жорен, імпульс сили жорна, ривок жорна. 